\title{
Cardiovascular risk and quality of life in elderly people with mild thyroid hormone deficiency
}

\section{Sara Tognini, Giuseppe Pasqualetti, Valeria Calsolaro, Antonio Polini, Nadia Caraccio and Fabio Monzani *}

Geriatrics Unit, Department of Clinical and Experimental Medicine, University of Pisa, Pisa, Italy

\section{Edited by:}

Andrzej Bartke, Southern Illinois

University School of Medicine, USA

\section{Reviewed by:}

Carmel Fratianni, Southern Illinois

University School of Medicine, USA

Peter J. Toth, University of Oklahoma

Health Sciences Center, USA

Ana Maria Buga, University of

Medicine and Pharmacy Rostock,

Germany

*Correspondence:

Fabio Monzani, Geriatrics Unit,

Department of Clinical and

Experimental Medicine, University of

Pisa, Via Paradisa, Pisa 56100, Italy

e-mail: fabio.monzani@med.unipi.it
Subclinical hypothyroidism (sHT) is a common condition in the general population, the prevalence increases with age, especially in women. An association between sHT and increased coronary heart disease (CHD) and heart failure (HF) risk and mortality has been described. However, this association is far to be established in older people (>65 years), especially in the oldest old (>85 years). Individuals with sHT may experience symptoms that resemble those observed in the overt form of the disease, leading to an impaired quality of life ( $\mathrm{OoL})$. Although very old people are frequently frail and potentially more susceptible to the effects of a disease, few studies were designed to assess the effect of sHT on QoL in this subset of population. Interestingly, the serum TSH concentration curve of general population has a skewed distribution with a "tail" toward higher values, which is amplified with aging. Thus, the diagnosis of $\mathrm{sHT}$ and the interpretation of its potential effects on CV function and QoL in older people may be a challenge for the clinician. Giving these premises, we reviewed the English scientific literature available on National Library of Medicine (www.pubmed.com) since 1980 regarding hypothyroidism, sHT, elderly, cardiovascular risk, CHD or HF events and mortality, health-related QoL, and LT4 therapy. Consistent results among large prospective cohort studies suggest an age-independent relationship between sHT and HF progression, while an impact of sHT on $\mathrm{CHD}$ events and mortality is essentially reported in young adults (aged below 65-70years) with longlasting disease. Scanty data are available on QoL of older people with $\mathrm{SHT}$ (>65 years) and, generally, no significant alterations are described.

Keywords: elderly, subclinical hypothyroidism, quality of life, cardiovascular risk, cardiovascular events, heart failure, ischemic heart disease, mortality

\section{INTRODUCTION}

Subclinical hypothyroidism (sHT), defined as serum TSH concentration above the upper limit of the reference range in the face of normal free $\mathrm{T}_{4}\left(\mathrm{FT}_{4}\right)$ and free $\mathrm{T}_{3}\left(\mathrm{FT}_{3}\right)$ levels, is a common condition in older people, especially among women (1-3). This biochemical condition encompasses several pathological entities, mainly represented by chronic autoimmune thyroiditis. sHT is often associated to symptoms that resemble those of overt hypothyroidism, although to a lesser extent thus, the expression "mild thyroid impairment" or "mild thyroid hormone deficiency" would be more appropriate for defining such a condition (1). Nonetheless, the term sHT is recognized worldwide and will be utilized in the present review, too. In the last decades, an association between sHT and increased cardiovascular $(\mathrm{CV})$ risk has been described, although depending on the degree of TSH elevation (1, $4,5)$. However, this relationship in older individuals is far to be established (6-9). Although very old people are frequently frail and potentially more susceptible to the effects of a disease, few studies were designed to assess the effect of sHT on quality of life $(\mathrm{QoL})$ in this subset of population. Moreover, the serum TSH concentration curve of general population has a skewed distribution with a "tail" toward higher values, which is amplified with aging $(6,7)$. Thus, the diagnosis of sHT and the interpretation of its potential effects on CV function and QoL in older people may be a challenge for the clinician. Thus, better understanding of these topics could, at least partially, resolve the question of whether treating older people, especially the oldest old (aged $>85$ years), with sHT is appropriate, especially in case of slight elevation (from $>4$ to $<10 \mathrm{mIU} / \mathrm{l}$ ) of serum TSH value. Given these premises, we reviewed the English scientific literature available on National Library of Medicine (www.pubmed.com) since 1980 regarding hypothyroidism, sHT, elderly, CV risk, coronary heart disease (CHD) or heart failure (HF) events and mortality, health-related QoL, and LT4 therapy.

\section{THYROID FUNCTION AND AGING}

The relationship between thyroid function and aging has been hypothesized more than almost two decades ago (8). Several clinical studies confirmed an age-dependent decrease of thyroid function including iodine uptake and thyroid hormone production (9). However, it should be underlined that direct age-related changes need to be distinguished from the actual alterations induced by thyroid diseases or non-thyroidal illness. In this setting, conflicting results still exist regarding the serum TSH reference range and its modification with aging between earlier reports (mainly casecontrol or cross-sectional) and recent large naturalistic studies (3, $7,8,10-14)$. Given that sHT is essentially recognized as abnormal serum TSH elevation, the definition of a worldwide recognized age-related reference range is clearly warranted. 
In the study by Mariotti et al. (8), healthy centenarians showed a relatively low prevalence of $\mathrm{sHT}(7 \%)$ in the face of reduced serum $\mathrm{FT}_{3}$ levels as compared to either young adults or older people ( $>65$ years). Interestingly, a progressive decrease of serum TSH levels from young adults up to older people and centenarians was observed. The study raised the question whether the decreased $\mathrm{FT}_{3}$ and TSH values represented an adaptive mechanism to reduced metabolic homeostasis or a protective condition in aging. Moreover, the age-related changes of thyroid status should be distinguished from the "no-thyroidal illness syndrome" (frequently observed in older people), in which serum $\mathrm{FT}_{3}$ decreases while $\mathrm{FT}_{4}$ (within the normal range of healthy adults) and reverse $\mathrm{T}_{3}$ (above the normal range of healthy adults) increase. Indeed, the low serum $\mathrm{T}_{3}$ of non-thyroidal illness syndrome reflects a catabolic state and is associated with a lower physical function and poorer prognosis $(15,16)$. At partial odds with the earlier reports $(8,14)$, more recent population-based and cross-sectional studies $(6,7)$ showed a progressive shift of the normal serum TSH range toward higher values from healthy young individuals up to centenarians. A possible interpretation of this finding could be the presence of low bioactive isoforms of circulating TSH (17). Since TSH bioactivity is related to post-translational modifications such as sialylation, sulfation, and glycosylation that could be affected by the aging process, TSH immunoreactivity cannot be assumed to represent TSH bioactivity at all. Thus, it is possible that differences in TSH bioactivity as well as alterations of renal or liver function could account for some of the discrepancies of literature in older people. Unfortunately, current assays for serum TSH measurement cannot distinguish different TSH isoforms and we can only speculate on this finding without certain evidences.

Overall, however, available data suggest that aging is associated with a certain degree of down-regulation of the hypothalamus pituitary-thyroid-peripheral axis, although the clinical significance of such condition and the effectiveness of $\mathrm{LT}_{4}$ replacement therapy are far to be established, especially in the elderly $(9,18)$. Indeed, thyroid hormones $(\mathrm{TH})$ are implicated in maintaining and integrating metabolic homeostasis at multiple levels, notably not only in the hypothalamus but also in peripheral tissues. In detail, TH may affect cell membrane composition, inflammatory response, and stem cell renewal. Interestingly, data from both human beings and animal models showed a negative correlation between serum $\mathrm{TH}$ value and longevity. Bowers et al. (19) recently reviewed the available literature on the putative TH-related mechanisms that could be implicated in modulating lifespan of mammals, including human beings. They argued that constraints on $\mathrm{TH}$ signaling at certain life stages, notably during old age, could be advantageous for optimal aging. Accordingly, Rozing et al. reported that the offspring of nonagenarian siblings presented a lower thyroidal sensitivity to TSH and a paradoxical beneficial cardio-metabolic profile as compared to their partners (20). Moreover, better survival and performance status has been described in very old people ( $>85$ years) with mild thyroid failure (10, 21-23).

As a whole, these findings suggest that a certain degree of downregulation of thyroid function may exert a beneficial effect during aging and might represent a protective factor in the oldest old population. It should be underlined, however, that most data were obtained in animal models, mainly rodents, and a parallel with human beings should be cautiously interpreted.

\section{EPIDEMIOLOGY OF sHT}

Human aging, especially in women, is associated with increased prevalence of circulating anti-thyroid antibodies and mild to fullblown thyroid failure $(2,3,10,18,24,25)$. In this setting, however, the sensitivity of the TSH assay utilized in the study and the cut-off value used for defining $\mathrm{sHT}$, which ranged from $>3.0$ to $>7.0 \mathrm{mIU} / \mathrm{l}(26,27)$ should be taken into account. Moreover, giving the high prevalence of anti-thyroid antibodies observed in individuals with circulating TSH value above $2.5 \mathrm{mIU} / \mathrm{l}$, such cutoff has been also proposed for defining $\operatorname{sHT}(28,29)$. Thus, it is not surprising that the reported prevalence of sHT ranges widely from 1.3 to $21 \%(24-27,30-32)$. Besides the different cut-off values, another factor responsible for the wide variability of sHT prevalence is the heterogeneity of the population analyzed in each trial, which differs in relation to age, lifestyle, comorbidity, treatments, and ethnicity as well as the different degrees of iodine intake (18). Indeed, in people with sufficient iodine intake, a higher prevalence of both thyroid autoimmunity and hypo is generally observed as compared to individuals living in iodine insufficient areas (33). Accordingly, in the Wickham survey, the prevalence of sHT was $7.5 \%$ but rose from 7.5 to $17.4 \%$ while considering older women ( $>75$ years) with positive serum anti-thyroid antibody titers (28). In the Colorado STUDY, $21 \%$ of women and $16 \%$ of men older than 74 years suffered from mild thyroid deficiency (10). Interestingly, the prevalence of sHT decreased by $2 \%$ for patients older than 75 years and by $5 \%$ for those older than 90 years while using an age-specific reference range $(7,12,24)$. Another crucial aspect to keep in mind is the rate of progression from mild to overt hypothyroidism. Indeed, a significant number of subjects experienced no progression and even normalization of serum TSH value $(34,35)$.

In conclusion, the prevalence and the clinical impact of sHT as reported by scientific literature always should be interpreted in relation to the demographic, ethnic, and lifestyle characteristics of the studied population. Moreover, the actual presence of sHT should be confirmed by at least two measurements, with sufficient interval, of serum TSH level.

\section{THYROID HORMONES AND THE CARDIOVASCULAR SYSTEM}

Subclinical hypothyroidism might be interpreted as an intermediate alteration between full-blown thyroid failure and euthyroidism. Thus, changes of CV system induced by sHT qualitatively resemble those observed in overt hypothyroidism even if less evident. Since TH influence each structure of the heart and its conducting system, the relationship between thyroid dysfunction and $\mathrm{CV}$ disease goes well beyond the risk of atherosclerosis and atrial fibrillation $(1,36,37)$. $\mathrm{TH}$, mainly $\mathrm{FT}_{3}$, regulate myosin heavy chain genes, which encode for the two contractile protein isoforms of the thick filament of the cardiomyocyte (38-41). $\mathrm{TH}$ also induce expression of the sarcoplasmatic reticulum $\mathrm{Ca} 2-$ ATPase and reduce the expression of its inhibitor, phospholamban (42). Accordingly, reduced heart output along with prolonged isovolumic relaxation phase, leading to an early cardiac impairment, has been described in hypothyroidism (43). Many studies 
documented similar alteration also in sHT patients (44-46). Systolic function impairment with increased pre-ejection/ejection time ratio and mean aortic acceleration has been shown in sHT patients (47-49). Decreased cardiac preload along with increased after load, leading to a reduction of cardiac output, was confirmed by magnetic resonance study (50). Interestingly, similar functional modifications are described during the aging process, thus it is not surprising that sHT may worsen the age-related cardiac process resulting in increased risk of HF progression and events (51). Moreover, cardiac alterations associated with sHT are generally reversed after restoration of euthyroidism by L-thyroxine replacement $(44,47,52)$.

Thyroid hormones also affect endothelium and smooth muscle cell function, leading to reduced vascular tone (38). Several mechanisms for $\mathrm{T}_{3}$-mediated vascular relaxation have been reported $(37,38,53,54)$. As stated by Klein et al., $\mathrm{T}_{3}$ induces in vitro relaxation of smooth muscle cells independently of $\mathrm{NO}$ production, suggesting a direct effect of the hormone (38). Dardano et al. showed that, in patients monitored for differentiated thyroid cancer, the administration of recombinant human TSH acutely impaired endothelium-dependent vasodilation, possibly through the induction of low-grade inflammation and reduced NO availability by oxidative stress, suggesting a possible role of TSH per se in endothelial dysfunction (55). Moreover, sympathetic and adrenal activation may contribute to the development of arterial hypertension in hypothyroid individuals (56-58).

Overall, these findings suggest that sHT affects CV system by complex mechanisms involving both myocardium and vasculature. These effects are partially similar to those typically observed in the aging process, making difficult to distinguish CV changes of aging from those directly belonging to sHT. Both the degree of serum TSH increase and its long-lasting effect have been claimed to concur to the development of sHT effects at tissue level $(59,60)$. Thus, exposition to minute thyroid hormone deficiency may, over time, be associated with increased risk of CV diseases. However, the actual burden of mild thyroid failure on the CV system of older people remains to be established and still is widely debated $(1,38)$.

\section{HEART FAILURE AND SHT IN THE ELDERLY}

Heart failure, defined as an impaired ability of the ventricle to fill with or eject blood, represents a common clinical condition with increasing prevalence in the last decades of life $(61,62)$. More than 20 million people suffer from HF worldwide (63), and its prevalence and incidence are increasing mostly because of increasing lifespan, and also because of increased prevalence of risk factors (diabetes mellitus, systemic hypertension, dyslipidemia) and improved survival rates from other types of CV diseases (64). In 2011, HF was the most common reason for hospitalization for individuals older than 85 years and the second most common for those aged $65-85$ years (65). Since sHT has been described to be associated with conditions that may concur to the development of HF (66-68), several prospective studies have been designed to evaluate the possible relationship between mild thyroid dysfunction and $\mathrm{HF}$ with discordant results $(66,69-71)$. As above described, the effect of TH deficiency on CV system is partially similar to that typically observed in the aging process (interstitial fibrosis, myocyte loss, cardiac remodeling). However, few studies directly examined the relationship between sHT and HF in elderly people (70-75). Rodondi et al. studied 3044 adults older than 65 years and initially free of HF over a mean 12-year follow-up (70). An increased risk of HF was observed in subjects with TSH above $10.0 \mathrm{mIU} / \mathrm{l}$ with HF incidence of $41.7 / 1000$ vs $22.9 / 1000$ person per year in euthyroid individuals $(p=0.01)$. Interestingly, no increased incidence was observed in subjects with serum TSH level between 4.5 and $9.9 \mathrm{mIU} / \mathrm{l}$, even after stratification by TSH concentration below or above $6.9 \mathrm{mIU} / \mathrm{l}$. Accordingly, among 5316 older adults (aged 70-82 years) an increased HF risk (HR 3.0, 95\%CI: 1.12-8.11) was observed only in individuals with serum TSH value above $10.0 \mathrm{mIU} / \mathrm{l}$ after 3.2 years of follow-up (51). Nonetheless, in a previous study on community-dwelling older people (2730 subjects aged 70-79 years with a follow-up of 4 years) those with serum TSH level between 7.0 and $10.0 \mathrm{mIU} / \mathrm{l}$ showed an increased risk of HF (HR 2.58, 95\% CI: 1.19-5.60) but not of other CV events or mortality (72). Moreover, mild elevated TSH $(<10.0 \mathrm{mIU} / \mathrm{l})$ represented a negative prognostic factor for increased cardiac and all-cause mortality in hospitalized patients (3121 patients, mean age 61.1 years) with acute HF events (73).

At odds with these results, in a study performed in 5888 community-dwelling individuals aged over 65 years, those with sHT did not show an increased HF risk, even for TSH values above $10.0 \mathrm{mIU} / \mathrm{l}$. Moreover, in a time-varying model, in which thyroid status was updated with subsequent TSH measurements, there was no association between sHT and incident HF (74). Similarly, patients older than 60 years with serum TSH value above 5.0 but less than $8.0 \mathrm{mIU} / \mathrm{l}$ did not show an increased risk of hospitalization for HF (HR 1.23, 95\% CI: 0.96-1.56) (75). The lack of an association between mild thyroid failure and HF was also reported by a very recent prospective study in subjects aged over 65 years (76). Possible explanations of these conflicting results may be the different ethnic compositions, mean age, and comorbidity of the study populations as well as the different degrees of serum TSH elevation and length of follow-up. Moreover, since in many individuals TSH normalizes over time (15-65\% over follow-up periods going from 1 to 6 years), a possible fluctuation of thyroid dysfunction over time might have contributed to the negative findings of some studies, especially in case of single serum TSH determination (35).

In conclusion, most studies showed an increased risk of $\mathrm{HF}$ progression and events in sHT patients, although with different strengths of association and, generally, for serum TSH value above $10.0 \mathrm{mIU} / 1$ (51, 70-72). Accordingly, a recent meta-analysis of 6 large, prospective studies on community-dwelling older individuals confirmed that sHT patients have an age-independent increased rate of HF, although only for serum TSH value above $10.0 \mathrm{mIU} / \mathrm{l}$ (77). Finally, although small case-control studies, mainly performed in young adults, have shown that restoration of euthyroidism by $\mathrm{LT}_{4}$ therapy is able to improve indexes of cardiac function $(47,52)$; no large, randomized, controlled trials have been performed to date to evaluate the efficacy of $\mathrm{LT}_{4}$ replacement in preventing HF progression and events.

\section{CORONARY HEART DISEASE AND SHT IN THE ELDERLY}

Conflicting data still exist regarding the association between sHT and CHD; some studies reporting increased risk $(4,5,78)$, some 
decreased (76), and some the lack of any association (72, 7983). Since inconsistent data were especially obtained in the elderly (Table 1) the risk of CHD in sHT patients has been suggested to be confined to young adults ( $<65$ years). Nonetheless, most reports did not accurately explore the possible age-related differences in CHD risk, even in case the elderly represented a large share of the enrolled population.

In this setting, a recent large meta-analysis showed no evidence of a gradient of CHD risk while stratifying data by age (93). Moreover, in the Rotterdam study [1149 postmenopausal women aged $69.0 \pm 7.5$ years (mean \pm SD)] $\mathrm{sHT}$ was associated with a greater age-adjusted prevalence of aortic atherosclerosis [odds ratio, 1.7 (95\% CI 1.1-2.6)] and myocardial infarction [MI, odds ratio, 2.3 (95\% CI 1.3-4.0)]. Additional adjustment for body mass index, lipoprotein profile, systemic blood pressure, and smoking status, as well as the exclusion of women taking beta-blockers, did not affect these estimates (84). Similarly, Lindeman et al. documented a significantly higher prevalence of CHD in patients older than 65 years with elevated serum TSH $(>10.0 \mathrm{mIU} / \mathrm{l})$ as compared to those with normal TSH value (85). Conversely, most naturalistic studies did not find any association between sHT and increased CHD events or mortality among older people $(86-90,92)$, even if one documented increased all-cause mortality (81). The Women's Health Initiative survey (90) examined the association between sHT and MI by measuring serum TSH and $\mathrm{FT}_{4}$ in 736 women with incident $\mathrm{MI}$ as compared to 2974 randomly selected individuals. After 5-10 years of follow-up, the Hazard ratio for MI was 0.99 (95\% CI: 0.67-1.46) for women with serum TSH between 4.69 and $6.99 \mathrm{mIU} / \mathrm{l}$, and 1.19 (95\% CI: 0.72-1.96) for those with TSH $\geq 7.0 \mathrm{mIU} / \mathrm{l}$ (90). It should be underlined, however, that no information about the use of thyroid medication was available beyond 3 years of follow-up and thyroid function testing was performed only at the beginning. However, Hyland et al., in a prospective study on 4863 older people ( $>65$ years), in which thyroid status was updated with subsequent TSH measurements, did not find any association between persistent or transient sHT and incident CHD (HR 1.37, 95\% CI: 1.00-1.87 and HR 1.00, 95\% CI: 0.68-1.49, respectively) or CV death (HR 0.97, 95\% CI: 0.64-1.48 and HR 0.99, 95\% CI: 0.701.39 , respectively). Additional analysis stratified by the degree of serum TSH elevation (4.5-6.9; 7.0-9.9, and 10.0-19.9 mIU/l) confirmed the negative findings (74). Another prospective study on 1587 community-dwelling older men ( $>65$ years) did not find any association between sHT and CV events or total mortality notwithstanding the rate of TSH elevation, but serum TSH higher than $10.0 \mathrm{mIU} / \mathrm{l}$ was detected only in eight men (89). Moreover, a cross-sectional study with subgroup analyses by age confirmed that increased CHD risk was present only in younger sHT participants ( $<50$ years old) (94). Accordingly, a meta-analysis of five studies demonstrated that sHT is associated with increased CHD prevalence and events only in young adults (aged $<65$ years), in whom an increased incidence of CHD was observed also for serum TSH value lower than $10.0 \mathrm{mIU} / \mathrm{l}$ (95). Interestingly, a very large, recent meta-analysis clearly demonstrated that, in age- and sexadjusted analyses, the risk of CHD events and mortality increases with rising serum TSH level, reaching the statistical significance only in patients with TSH values above $10 \mathrm{mIU} / \mathrm{l}$ regardless of patients' age (93).
In summary, the negative effect of sHT on CHD events and mortality appears well established in subjects younger than 65 years but less evident in older people. The inconsistency in results among studies in elderly patients may be due either to the duration of tissue exposure to sHT or of follow-up, as well as to the presence or not of comorbidity (pre-existing CV or other chronic diseases). The most representative meta-analyses on the association between sHT and CHD risk are reported in Table 2.

\section{CEREBROVASCULAR DISEASE AND sHT}

Subclinical hypothyroidism is postulated to increase stroke risk via atherogenic changes associated with abnormal thyroid function. However, the direct relationship of sHT with subsequent stroke is poorly studied. Some naturalistic studies suggest that sHT is not associated to cerebral ischemic events, and a better outcome of patients affected by sHT with respect to those without thyroid failure has been reported $(72,98,99)$. In detail, a large naturalistic study (2730 individuals aged 70 to 79 years) with 4 -year follow-up data showed that sHT was not associated with a higher prevalence of either CV events (including stroke) or total mortality (80). Schultz et al. (99) prospectively evaluated 609 communitydwelling individuals older than 50 years showing no increase of incident stroke among sHT subjects also after adjusting data by the degree of serum TSH elevation. These data are partially at odds with those from the Women's Health Initiative Observational Study (98), in which the potential relationship between incident ischemic stroke and severity of sHT was prospectively assessed in postmenopausal women (639 ischemic stroke cases and 2927 randomly selected sub-cohort members with 7 years of follow-up). The adjusted hazard ratio from weighted Cox models resulted modestly elevated $(1.22,95 \% \mathrm{CI}, 0.73,2.05)$ only for sHT women with serum TSH value higher than $7.00 \mathrm{mIU} / \mathrm{l}$. However, giving the wide range of $95 \% \mathrm{CI}$, the data appeared not sufficiently consistent to suggest a clear-cut association between $\mathrm{sHT}$ and ischemic stroke, in otherwise healthy postmenopausal women. In this setting, it is noteworthy that among 756 patients with acute ischemic stroke those with sHT at admission were more likely to show favorable functional outcomes (100).

In conclusion, available data suggest that sHT has no impact on cerebral ischemic events or the effect is too small to be detected in naturalistic studies. Preconditioning before stroke along with reduced response to stress could represent the possible protective mechanism exerted by sHT in the outcome of patients with stroke. More studies are clearly warranted to better address this topic with dedicated epidemiological assessment.

\section{SHT AND CV MORTALITY}

Although an association between sHT and a greater all-cause and CV mortality $(73,87,101,102)$ has been generally documented in individuals with underlying high $\mathrm{CV}$ risk (patients at high risk for or who had recent cardiac events), it has not always been observed in general population $(23,72,79,80,88,89)$. Indeed, a large population-based, longitudinal study of CHD and stroke in subjects older than 65 years failed to support the hypothesis of an association between unrecognized sHT and increased CV events or mortality (80). Although no difference in the association between sHT and mortality among patients with and without 
Table 1 | Most representative prospective or cross-sectional studies on subclinical hypothyroidism and cardiovascular risk

\begin{tabular}{|c|c|c|c|c|c|c|c|c|}
\hline Reference & Study design & $\begin{array}{l}\text { Study } \\
\text { population }\end{array}$ & $\begin{array}{l}\text { Participants } \\
\text { (sHT) }\end{array}$ & Age (years) & TSH (mIU/I) & $\begin{array}{l}\text { Follow-up } \\
\text { (years) }\end{array}$ & $\begin{array}{l}\text { Analyzed } \\
\text { endpoint }\end{array}$ & Outcome \\
\hline Hak et al. (84) & Cross-sectional & $\begin{array}{l}\text { Postmenopausal } \\
\text { women }\end{array}$ & $1149(124)$ & $96.0 \pm 7.9$ & $>4.00$ & NA & CVE & OR $2.3(\mathrm{Cl} 1.3-4.2)$ \\
\hline Parle et al. (83) & Prospective & $\begin{array}{l}\text { Community } \\
\text { dwelling }\end{array}$ & $1120(94)$ & $>60$ & $>5.00$ & 10 & CVM & HR 0.9 (Cl 0.6-1.3) \\
\hline Lindeman et al. (85) & Cross-sectional & $\begin{array}{l}\text { Community } \\
\text { dwelling }\end{array}$ & 755 (112) & $74.1 \pm 8.2$ & NA & NA & CVE & $p=0.0007(\mathrm{TSH}>10.0)$ \\
\hline \multirow[t]{2}{*}{ Imaizumi et al. (78) } & Prospective & $\begin{array}{l}\text { Community } \\
\text { dwelling }\end{array}$ & $2650(257)$ & $62.7 \pm 11.1$ & $7.16 \pm 4.82$ & 12.2 & $\mathrm{ACM}$ & $\begin{array}{l}\text { HR } 1.9 \text { (Cl 1.1-3.2), } \\
\text { in men only }\end{array}$ \\
\hline & & & & & & & CVE & OR $2.5(\mathrm{Cl} 1.1-5.5)$ \\
\hline Gussekloo et al. (23) & Prospective & $\begin{array}{l}\text { Community } \\
\text { dwelling }\end{array}$ & $502(30)$ & $>85$ & $>4.8$ & 4 & $\mathrm{ACM}$ & HR $0.76(0.62-0.92)$ \\
\hline van den Beld et al. (22) & Prospective & $\begin{array}{l}\text { Community } \\
\text { dwelling }\end{array}$ & $359(6)$ & 77.8 (73-94) & $>4.3$ & 4 & Survival & NS \\
\hline Cappola et al. (80) & Prospective & $\begin{array}{l}\text { Community } \\
\text { dwelling }\end{array}$ & $3135(496)$ & $72.7 \pm 5.6$ & $6.67 \pm 2.54$ & 13 & $\begin{array}{l}\text { CVM, } \\
\text { CVE }\end{array}$ & $\begin{array}{l}\text { HR } 1.14 \text { (Cl 0.91-1.43), } \\
\text { HR 1.04(Cl 0.87-1.23) }\end{array}$ \\
\hline lervasi et al. (73) & Prospective & $\begin{array}{l}\text { Hospitalized } \\
\text { cardiac patients }\end{array}$ & $2113(208)$ & $61.1(60.7-61.5)$ & 6.7 (6.01-7.44) & 2.7 & $\begin{array}{l}\text { ACM, } \\
\text { CVM }\end{array}$ & $\begin{array}{l}\text { HR } 2.0 \text { (Cl 1.33-3.04), } \\
\text { HR 2.4 (Cl 1.36-4.21) }\end{array}$ \\
\hline Bauer et al.(86) & Prospective & $\begin{array}{l}\text { Community } \\
\text { dwelling }\end{array}$ & $438(37)$ & $71.5 \pm 5.0$ & $>5.50$ & 11.9 & Survival & HR 1.23 (Cl 0.55-2.74) \\
\hline Razvi et al.(5) & Prospective & $\begin{array}{l}\text { Community } \\
\text { dwelling }\end{array}$ & $2376(97)$ & $49.9 \pm 17.9$ & $6.00-15.00$ & 20 & $\begin{array}{l}\text { CVE, } \\
\text { CVM }\end{array}$ & $\begin{array}{l}\mathrm{HR} 1.76(\mathrm{Cl} 1.15-2.71) \\
\operatorname{HR} 1.79(1.02-3.56) 1\end{array}$ \\
\hline McQuade et al. (87) & Retrospective & $\begin{array}{l}\text { Community } \\
\text { dwelling }\end{array}$ & $6240(1396)$ & $\begin{array}{c}\text { EU: } 54.6 \pm 12.7, \text { Mild } \\
\text { sHT: } 57.1 \pm 13.3 \\
\text { Moderate sHT: } \\
58.9 \pm 13.6\end{array}$ & $\begin{array}{c}\text { Mild sHT: 3.1-6.0, } \\
\text { Moderate sHT: } \\
6.1-10.0\end{array}$ & 8 & $\mathrm{ACM}$ & $\begin{array}{c}p=0.026 \text { in moderate } \\
\text { sHT people } \\
\text { aged }>65 \text { years }\end{array}$ \\
\hline de Jongh et al. (88) & Prospective & $\begin{array}{l}\text { Community } \\
\text { dwelling }\end{array}$ & 1219 (34) & $>65$ & $6.89(5.65-9.59)$ & 10.7 & $\begin{array}{l}\text { ACM, } \\
\text { CVM }\end{array}$ & $\begin{array}{l}\text { HR } 0.9 \text { (Cl 0.58-1.42), } \\
\text { HR } 0.5 \text { (Cl 0.20-1.49) }\end{array}$ \\
\hline Waring et al. (89) & Prospective & $\begin{array}{l}\text { Community } \\
\text { dwelling }\end{array}$ & $1503(116)$ & 74 & $4.79-10.00$ & 8.3 & $\begin{array}{l}\text { ACM, } \\
\text { CVM }\end{array}$ & $\begin{array}{l}\text { HR } 1.01 \text { (Cl 0.7-1.4), } \\
\text { HR } 1.28 \text { (Cl 0.8-2.1) }\end{array}$ \\
\hline
\end{tabular}




\section{Table 1 | Continued}

\begin{tabular}{|c|c|c|c|c|c|c|c|c|}
\hline Reference & Study design & $\begin{array}{l}\text { Study } \\
\text { population }\end{array}$ & $\begin{array}{l}\text { Participants } \\
\text { (sHT) }\end{array}$ & Age (years) & TSH (mIU/I) & $\begin{array}{l}\text { Follow-up } \\
\text { (years) }\end{array}$ & $\begin{array}{l}\text { Analyzed } \\
\text { endpoint }\end{array}$ & Outcome \\
\hline Hyland et al. (74) & Prospective & $\begin{array}{l}\text { Community } \\
\text { dwelling }\end{array}$ & $4863(697)$ & $73.4 \pm 5.7$ & $6.7 \pm 2.6$ & 10 & $\begin{array}{l}\text { CVE, } \\
\text { CVM }\end{array}$ & $\begin{array}{l}\text { HR } 1.37 \text { (Cl 1.0-1.87), } \\
\text { HR } 0.89 \text { (Cl 0.64-1.48) }\end{array}$ \\
\hline LeGrys et al. $(90)^{a}$ & Prospective & $\begin{array}{l}\text { Postmenopausal } \\
\text { women }\end{array}$ & $3663(282)$ & $65-79$ & $>4.69$ & $>5$ & $\begin{array}{c}\text { CVE: } \\
\text { TSH 4.69-6.99, } \\
\text { TSH > 7.00, } \\
\text { TSH 4.69-6.99, } \\
\text { TSH }>7.00\end{array}$ & $\begin{array}{c}\text { Age 65-70: } \\
\text { HR } 0.99 \text { (Cl 0.42-2.35), } \\
\text { HR 1.11 (Cl 0.51-2.39); } \\
\text { Age 71-79: } \\
\text { HR } 0.53 \text { (Cl 0.13-2.26), } \\
\text { HR } 1.27 \text { (Cl } 0.44-3.69)\end{array}$ \\
\hline Rhee et al. (91) & Prospective & $\begin{array}{l}\text { Community } \\
\text { dwelling }\end{array}$ & $2570(691)$ & sHT: $59.2 \pm 19.2$ & $6.3(5.3-8.72)$ & 14.3 & $\mathrm{ACM}$ & $\begin{array}{l}\text { Pre-existing HF: } \\
\text { HR 1.77 (Cl 1.19-2.64), } \\
\text { No pre-existing HF: } \\
\text { HR } 0.97 \text { (Cl 0.84-1.12) }\end{array}$ \\
\hline Ceresini et al. (92) & Prospective & $\begin{array}{l}\text { Community } \\
\text { dwelling }\end{array}$ & $951(29)$ & $>65$ & $>4.68$ & 6 & CVM & HR 0.50 (Cl 0.10-2.55) \\
\hline Yeap et al. (82) & Prospective & $\begin{array}{l}\text { Community } \\
\text { dwelling men }\end{array}$ & 3885 (416) & $70-89$ & $>4.00$ & $6.4 \pm 1.5$ & $\mathrm{ACM}$ & HR 1.06 (Cl 0.86-1.32) \\
\hline Frey et al. (69) & Prospective & $\begin{array}{l}\text { Hospitalized } \\
\text { cardiac patients }\end{array}$ & $1032(34)$ & sHT $62 \pm 12$, EU $67 \pm 13$ & $5.29(4.02-9.38)$ & $3.08(1.5-3.58)$ & $\mathrm{ACM}$ & HR 0.96 (Cl 0.52-1.77) \\
\hline Perez et al. $(75)^{b}$ & Prospective & $\begin{array}{l}\text { Community } \\
\text { dwelling }\end{array}$ & $4987(237)$ & $>60$ & $6.40(5.60-8.00)$ & 2.73 & $\begin{array}{l}\text { CVM, } \\
\text { ACM }\end{array}$ & $\begin{array}{l}\text { HR } 1.46 \text { (Cl 1.16-1.84), } \\
\text { HR } 1.36 \text { (Cl 1.03-1.76) }\end{array}$ \\
\hline
\end{tabular}

${ }^{a}$ First-time incident myocardial infarction.

${ }^{5} T S H$ value lower than $8.00 \mathrm{~m} / \mathrm{U} / \mathrm{l}$ but no distinction between sHT and overt hypothyroidism. Age and TSH value are reported as mean $\pm S D$ or median (confidence interval or range).

sHT, subclinical hypothyroidism; EU, euthyroidism; HR, hazard ratio; OR, odds ratio; ACM, all-cause mortality; CVM, cardiovascular mortality; CVE, cardiovascular events; NS, not significant; NA, not available. 
Table 2 | Most representative meta-analyses on the relationship between subclinical hypothyroidism and coronary heart disease.

\begin{tabular}{|c|c|c|c|c|c|c|}
\hline \multirow[t]{2}{*}{ Reference } & \multirow{2}{*}{$\begin{array}{l}\text { Number } \\
\text { of studies }\end{array}$} & \multirow{2}{*}{$\begin{array}{l}\text { Study population } \\
\text { (subjects with sHT) }\end{array}$} & \multirow[t]{2}{*}{ Age } & \multirow[t]{2}{*}{ Endpoint } & \multicolumn{2}{|c|}{ Outcome } \\
\hline & & & & & Whole cohort & Subjects older than 65 years \\
\hline $\begin{array}{l}\text { Singh et al. } \\
\text { (97) }\end{array}$ & 6 & 11,495 (935) & $58-75$ & $\begin{array}{l}\text { CHD events } \\
\text { CVM }\end{array}$ & $\begin{array}{l}\mathrm{RR} 1.18(\mathrm{Cl} 1.02-1.37) \\
\mathrm{RR} 1.11(\mathrm{Cl} 0.99-1.25)\end{array}$ & NA \\
\hline \multirow[t]{2}{*}{ Ochs et al. (66) } & 10 & $14,449(1491)$ & $46-85$ & CHD events & HR 1.20 (95\% Cl 0.97-1.49) & $\begin{array}{l}<80 \text { and } \mathrm{HR} 1.06(95 \% \mathrm{Cl} 0.91-1.24) \\
>80 \text { and } \mathrm{HR} 0.47(95 \% \mathrm{Cl} 0.11-1.90)\end{array}$ \\
\hline & & & & CVM & HR 1.18 (95\% Cl 0.98-1.42) & $\begin{array}{l}<80 \text { and HR } 1.12 \text { (95\% Cl 0.99-1.28) } \\
>80 \text { and HR } 0.55 \text { (95\% Cl 0.24-1.25) }\end{array}$ \\
\hline & & & & CVM & HR 1.09 (95\% Cl 0.96-1.24) & $\begin{array}{l}<80 \text { and HR } 1.32(95 \% \mathrm{Cl} 1.08-1.62) \\
>80 \text { and HR } 1.01(95 \% \mathrm{Cl} 0.62-1.63)\end{array}$ \\
\hline
\end{tabular}

sHT, subclinical hypothyroidism; CHD, coronary heart disease; CVM, cardiovascular mortality; HR, hazard ratio; NA, not available.

underlying CV disease was detected by Rodondi et al. (93), in a more recent meta-analysis, pre-existing congestive HF significantly worsened the relationship between sHT and HF events (77). It is plausible that subpopulations with congestive HF may be predisposed to cardiac morbidity and mortality associated with sHT. In agreement with this hypothesis, only sHT patients (aged $59.2 \pm 19.2$ years, mean $\pm \mathrm{SD}$ ) with congestive HF showed a greater risk of all-cause mortality compared to euthyroid individuals (HR 1.77, 95\% CI: 1.19-2.64) (91). Moreover, Iervasi et al., among 3308 patients attending a Cardiology Clinic, documented an increased risk of cardiac death in those with sHT (HR 2.40, 95\% CI: 1.36-4.21), after 32 months of follow-up (73). There are few clinical studies evaluating the effects of hormone replacement in sHT subjects and none aimed at determining the impact of $\mathrm{LT}_{4}$ treatment on total mortality, especially in older people. Previous research in this area has shown contradictory results, with some randomized, controlled trials showing an improvement of both dyslipidemia and surrogate endpoints of atherosclerosis $(36,103,104)$ not documented by previous, uncontrolled studies (105-108).

In conclusion, the relationship between mild thyroid failure and increased risk of cardiac and all-cause mortality is far from being established and widely accepted, especially in the elderly. A negative effect of sHT on HF progression and events nonetheless has been documented in older individuals with underlying high $\mathrm{CV}$ risk. Large, randomized intervention studies are currently ongoing in older people with sHT and will share new insight in this still unresolved issue (109).

\section{SHT AND QOL IN THE ELDERLY}

Quality of life has been defined by the World Health Organization as "an individual's perception of their position in life in the context of the culture and value system in which they live, and in relation to their goals, expectations, standards and concerns" (110). Thus, patients are the best judges of their own perceived QoL. Measuring health status is imperative, especially in case of chronic diseases in which long-term survival is not at risk and the goal of treatment is to maintain patients symptom-free and living in the community. Symptoms and QoL in hypothyroidism were assessed by a large number of instruments, which can be broadly divided into two categories: generic and disease specific (111); most used generic tools, validated in thyroid failure and used in various thyroid disorders, are the Short Form36 (SF-36), the Nottingham Health Profile (NHP), and the General Health Questionnaire (GHQ) (111-115). Various validated thyroid-specific questionnaires were also developed: the Chronic Thyroid Questionnaire (CTQ), the Underactive-Thyroid-Dependent Quality of Life Questionnaire (ThyDQoL). and the Underactive Thyroid Treatment Satisfaction Questionnaire (ThyTSQ) (116-119). It is well known that overt hypothyroidism slows metabolism, with classical symptoms as tiredness, fatigue, and weight gain, and induces neuromuscular symptoms and cognitive problems (1). Moreover, overt hypothyroidism is associated with high psychiatric morbidity, in particular depression and paranoid disorders $(120,121)$. Thus, it is not surprising that overt thyroid failure is associated with impaired QoL $(112,116,117,122)$. It is generally recognized that $\mathrm{sHT}$ encompasses symptoms comparable to those observed in the overt form of the disease, although to a lesser extent (10). Mild thyroid failure has been associated with mood and cognitive alterations as well as neuromuscular abnormalities $(48,120,121,123,124)$. To date, however, the literature regarding the effects of sHT on QoL is sparse and inconclusive $(114,115$, $117,125,126)$. The largest naturalistic study suggested that sHT does not significantly affect health-related QoL $(114,115)$, while 
other studies carried out in sHT patients referring to endocrine out-patient clinics documented a significant decrease of QoL (125, 127). Scanty data are also available on the effect of LT4 replacement therapy on QoL $(107,128-130)$. Some studies did not find a significant modification of health-related QoL $(107,128)$, while others documented an improvement by restoring euthyroidism (129-131). As in adult population, some observational studies suggested an association between sHT and mood disorders in older people that could worsen QoL $(120,132)$. In detail, in 323 subjects older than 60 years, Chueire et al. showed that sHT increases the risk for depression (OR 4.9, 95\% CI 2.8-8.6) (120). Moreover, of $163 \mathrm{sHT}$ older patients ( $>65$ years) attending a general medical clinic, $75 \%$ had a lifetime diagnosis of major depression compared with $18 \%$ of euthyroid subjects (132). Others studies, however, did not confirm this association $(23,88,126)$.

Although older individuals could be more susceptible to the effects of a disease for their possible frailty, few studies were specifically designed to assess the effect of sHT on QoL in older population $(126,133)$. Functional capacity as assessed by ADL and IADL plays a fundamental role in determining QoL of older people. The majority of the studies, however, reported no association between sHT and functional impairment $(23,96,126,133$, 134). Simonsick et al. documented that individuals aged between 70 and 79 years with mild TSH elevation ( $4.5-7 \mathrm{mIU} / \mathrm{L})$ had faster mean and usual gait speed and better cardiorespiratory fitness than euthyroid controls (96). In addition, a prospective, observational, population-based study carried out on 599 participants followed up from age 85 to 89 years showed no association between serum TSH and FT4 levels and disability in daily life, depressive symptoms, and cognitive impairment at baseline or during follow-up. Increasing serum TSH levels were associated with a lower mortality rate that remained after adjustments for baseline disability and health status (23). In a very recent population-based prospective study, the Octabaix study, 307 (184 females) inhabitants older than 85 years were submitted to complete multifunctional assessment, including Barthel and Lowton indexes, mini mental state examination (MMSE), mini nutritional assessment (MNA), gait rating scale, and quality of life test (EQ-VAS). Compared to euthyroid subjects $(n=280)$, those with sHT $(n=20)$ did not show any difference either in QoL, or in functional and cognitive status (133).

Overall, these data support the hypothesis that in the oldest old population, individuals with abnormally high levels of TSH do not experience adverse effects and may have a prolonged life span. The studies focused on a specific class of patients (older than 85 years), and the results should be carefully interpreted, also considering the weakness of observational studies. Nonetheless, these data together with the results obtained by Rozing et al. (20) that demonstrated a possible genetic predisposition of nonagenarians to a decrease function of hypothalamus-pituitary-thyroid axis suggest that the oldest old may represent a different population with respect to moderate old people or young adults. In this setting, however, the lack of association between mild hypothyroidism and poor QoL as assessed by SF-36 was observed also in individuals older than 65 years, without known thyroid disease who had participated in the Korean Longitudinal Study on Health and Aging (126). Thus, the observation of a progressive shift of the normal serum TSH range toward higher values from healthy young individuals up to centenarians (7) may indicate a certain degree of down-regulation of the hypothalamuspituitary-thyroid-peripheral axis and a possible adaptive response to age-related metabolic changes.

\section{CONCLUSION}

Consistent results among large prospective cohort studies suggest a relationship between sHT and HF progression and events in older people, while an impact of sHT in terms of CHD events and mortality is recognized only in young adults ( $<65$ years). Moreover, in the oldest old population ( $>85$ years) one study suggested that high levels of TSH not only do not exert adverse effects but also may favor a prolonged lifespan. Limited reports are available on QoL of elderly people, and the lack of an association between sHT and poor QoL is generally reported. Thus, moderately old patients (65-75 years) could be considered clinically similar to the adult population, albeit with a higher optimal TSH target value (around $2-3 \mathrm{mIU} / \mathrm{l}$ ), whereas oldest old subjects ( $>80-85$ years) should be carefully followed with a wait-and-see strategy, generally avoiding hormonal treatment $(18,135)$.

Large, randomized, prospective studies are nonetheless warranted to assess whether sHT actually affects CV disease progression and events as well as health-related QoL in older people, analyzing results according to the age groups of participants.

\section{AUTHOR CONTRIBUTIONS}

All the authors substantially contributed to the study for important intellectual content.

\section{REFERENCES}

1. Biondi B, Cooper DS. The clinical significance of subclinical thyroid dysfunction. Endocr Rev (2008) 29:76-131. doi:10.1210/er.2006-0043

2. Gharib H, Tuttle RM, Baskin HJ, Fish LH, Singer PA, McDermott MT. Subclinical thyroid dysfunction: a joint statement on management from the American Association of Clinical Endocrinologists, the American Thyroid Association, and the Endocrine Society. J Clin Endocrinol Metab (2000) 90:581-5. doi:10.1210/jc.2004-1231 discussion 586-7,

3. Hollowell JG, Staehling NW, Flanders WD, Hannon WH, Gunter EW, Spencer CA, et al. Serum TSH, T(4), and thyroid antibodies in the United States population (1988 to 1994): National Health and Nutrition Examination Survey (NHANES III). J Clin Endocrinol Metab (2002) 87:489-99. doi:10.1210/jcem. 87.2.8182

4. Walsh JP, Bremner AP, Bulsara MK, O’Leary P, Leedman PJ, Feddema P, et al. Subclinical thyroid dysfunction as a risk factor for cardiovascular disease. Arch Intern Med (2005) 165:2467-72. doi:10.1001/archinte.165.21.2467

5. Razvi S, Weaver JU, Vanderpump MP, Pearce SH. The incidence of ischemic heart disease and mortality in people with subclinical hypothyroidism: reanalysis of the Whickham survey cohort. J Clin Endocrinol Metab (2010) 95:1734-40. doi:10.1210/jc.2009-1749

6. Atzmon G, Barzilai N, Surks MI, Gabriely I. Genetic predisposition to elevated serum thyrotropin is associated with exceptional longevity. J Clin Endocrinol Metab (2009) 94:4768-75. doi:10.1210/jc.2009-0808

7. Surks MI, Hollowell JG. Age-specific distribution of serum thyrotropin and antithyroid antibodies in the US population: implications for the prevalence of subclinical hypothyroidism. J Clin Endocrinol Metab (2007) 92:4575-82. doi:10.1210/jc.2007-1499

8. Mariotti S, Barbesino G, Caturegli P, Bartalena L, Sansoni P, Fagnoni F, et al. Complex alteration of thyroid function in healthy centenarians. J Clin Endocrinol Metab (1993) 77:1130-4. doi:10.1210/jc.77.5.1130

9. Pasqualetti G, Tognini S, Polini A, Caraccio N, Monzani F. Is subclinical hypothyroidism a cardiovascular risk factor in the elderly? J Clin Endocrinol Metab (2013) 98:2256-66. doi:10.1210/jc.2012-3818 
10. Canaris GJ, Manowitz NR, Mayor G, Ridgway EC. The Colorado thyroid disease prevalence study. Arch Intern Med (2000) 160:526-34. doi:10.1001/archinte. 160.4 .526

11. Mariotti S, Franceschi C, Cossarizza A, Pinchera A. The aging thyroid. Endocr $\operatorname{Rev}$ (1995) 1:686-715. doi:10.1210/edrv-16-6-686

12. Bremner AP, Feddema P, Leedman PJ, Brown SJ, Beilby JP, Lim EM, et al. Age-related changes in thyroid function: a longitudinal study of a community-based cohort. J Clin Endocrinol Metab (2012) 97:1554-62. doi: 10.1210/jc.2011-3020

13. Sawin CT, Chopra D, Azizi F, Mannix JE, Bacharach P. The aging thyroid. Increased prevalence of elevated serum thyrotropin levels in the elderly. JAMA (1979) 242:247-50. doi:10.1001/jama.1979.03300030019013

14. Monzani F, Del Guerra P, Caraccio N, Del Corso L, Casolaro A, Mariotti S, et al. Age-related modifications in the regulation of the hypothalamic-pituitarythyroid axis. Horm Res (1996) 46:107-12. doi:10.1159/000185005

15. Wiersinga WM, van den Berghe G. Non-thyroidal illness syndrome. 9th ed. In: Braverman LE, Cooper D, editors. Werner \& Ingbar's the Thyroid: A Fundamental and Clinical Text. Philadelphia, PA: Lippincott Williams and Wilkins (2004). p. 246-63.

16. Tognini S, Marchini F, Dardano A, Polini A, Ferdeghini M, Castiglioni M, et al. Non-thyroidal illness syndrome and short-term survival in a hospitalised older population. Age Ageing (2010) 39:46-50. doi:10.1093/ageing/afp197

17. Estrada JM, Soldin D, Buckey TM, Burman KD, Soldin OP. Thyrotropin isoforms: implications for thyrotropin analysis and clinical practice. Thyroid (2014) 24:411-23. doi:10.1089/thy.2013.0119

18. Pearce SH, Brabant G, Duntas LH, Monzani F, Peeters RP, Razvi S, et al. 2013 ETA guideline: management of subclinical hypothyroidism. Eur Thyroid J (2013) 2:215-28. doi:10.1159/000356507

19. Bowers J, Terrien J, Clerget-Froidevaux MS, Gothié JD, Rozing MP, Westendorp RG, et al. Thyroid hormone signaling and homeostasis during aging. Endocr $\operatorname{Rev}(2013)$ 34:556-89. doi:10.1210/er.2012-1056

20. Rozing MP, Houwing-Duistermaat JJ, Slagboom PE, Beekman M, Frölich M, de Craen AJ, et al. Familial longevity is associated with decreased thyroid function. J Clin Endocrinol Metab (2010) 95:4979-84. doi:10.1210/jc.2010-0875

21. Corsonello A, Montesanto A, Berardelli M, De Rango F, Dato S, Mari V, et al. A cross-section analysis of FT3 age-related changes in a group of old and oldestold subjects, including centenarians' relatives, shows that a down-regulated thyroid function has a familial component and is related to longevity. Age Ageing (2010) 39:723-7. doi:10.1093/ageing/afq116

22. van den Beld AW, Visser TJ, Feelders RA, Grobbee DE, Lamberts SW. Thyroid hormone concentrations, disease, physical function, and mortality in elderly men. J Clin Endocrinol Metab (2005) 90:6403-9. doi:10.1210/jc.2005-0872

23. Gussekloo J, van Exel E, de Craen AJ, Meinders AE, Frölich M, Westendorp RG. Thyroid status, disability and cognitive function, and survival in old age. JAMA (2004) 292:2591-9. doi:10.1001/jama.292.21.2591

24. Samuels MH. Subclinical thyroid disease in the elderly. Thyroid (1998) 8:803-13. doi:10.1089/thy.1998.8.803

25. Tunbridge WM, Evered DC, Hall R, Appleton D, Brewis M, Clark F, et al. The spectrum of thyroid disease in a community: the Whickham survey. Clin Endocrinol (Oxf) (1977) 7:481-93. doi:10.1111/j.1365-2265.1977.tb01340.x

26. Kanaya AM, Harris F, Volpato S, Perez-Stable EJ, Harris T, Bauer DC. Association between thyroid dysfunction and total cholesterol level in an older biracial population: the health; aging and body composition study. Arch Intern Med (2002) 162:773-9. doi:10.1001/archinte.162.7.773

27. Rivolta G, Cerutti R, Colombo R, Miano G, Dionisio P, Grossi E. Prevalence of subclinical hypothyroidism in a population living in the Milan metropolitan area. J Endocrinol Invest (1999) 22:693-7. doi:10.1007/BF03343631

28. Vanderpump MP, Tunbridge WM, French JM, Appleton D, Bates D, Clark $\mathrm{F}$, et al. The incidence of thyroid disorders in the community: a twentyyear follow-up of the Whickham survey. Clin Endocrinol (1995) 43:55-68. doi:10.1111/j.1365-2265.1995.tb01894.x

29. Spencer CA, Schwarzbein D, Guttler RB, LoPresti JS, Nicoloff JT. Thyrotropin (TSH)-releasing hormone stimulation test responses employing third and fourth generation TSH assays. J Clin Endocrinol Metab (1993) 76:494-8. doi:10.1210/jc.76.2.494

30. Sawin CT, Castelli WP, Hershman JM, McNamara P, Bacharach P. The aging thyroid. Thyroid deficiency in the Framingham study. Arch Intern Med (1985) 145:1386-8. doi:10.1001/archinte.145.8.1386
31. Wang C, Crapo LM. The epidemiology of thyroid disease and implications for screening. Endocrinol Metab Clin North Am (1997) 26:189-218. doi:10.1016/S0889-8529(05)70240-1

32. Geul KW, van Sluisveld IL, Grobbee DE, Docter R, de Bruyn AM, Hooykaas $\mathrm{H}$, et al. The importance of thyroid microsomal antibodies in the development of elevated serum TSH in middle-aged women: associations with serum lipids. Clin Endocrinol (Oxf) (1993) 39:275-80. doi:10.1111/j.1365-2265.1993. tb02366.x

33. Szabolcs I, Podoba J, Feldkamp J, Dohan O, Farkas I, SajgÃ M, et al. Comparative screening for thyroid disorders in old age in areas of iodine deficiency, long-term iodine prophylaxis and abundant iodine intake. Clin Endocrinol (Oxf) (1997) 47:87-92. doi:10.1046/j.1365-2265.1997.2271040.x

34. Huber G, Staub JJ, Meier C, Mitrache C, Guglielmetti M, Huber P, et al. Prospective study of the spontaneous course of subclinical hypothyroidism: prognostic value of thyrotropin, thyroid reserve, and thyroid antibodies. J Clin Endocrinol Metab (2002) 87:3221-6. doi:10.1210/jcem.87.7.8678

35. Diez JJ, Iglesias P, Burman KD. Spontaneous normalization of thyrotropin concentrations in patients with subclinical hypothyroidism. J Clin Endocrinol Metab (2005) 90:4124-7. doi:10.1210/jc.2005-0375

36. Monzani F, Caraccio N, Kozàkowà M, Dardano A, Vittone F, Virdis A, et al. Effect of levothyroxine replacement on lipid profile and intima-media thickness in subclinical hypothyroidism: a double-blind, placebo-controlled study. J Clin Endocrinol Metab (2004) 89:2099-106. doi:10.1210/jc.2003-031669

37. Grais IM, Sowers JR. Thyroid and the heart. Am J Med (2014) 127:691-8. doi:10.1016/j.amjmed.2014.03.009

38. Klein I, Ojamaa K. Thyroid hormone and the cardiovascular system. $N$ Engl J Med (2001) 344:501-9. doi:10.1056/NEJM200102153440707

39. Yen PM, Ando S, Feng X, Liu Y, Maruvada P, Xia X. Thyroid hormone action at the cellular, genomic and target gene levels. Mol Cell Endocrinol (2006) 24:121-7. doi:10.1016/j.mce.2005.11.030

40. Kuzman JA, Gerdes AM, Kobayashi S, Liang Q. Thyroid hormone activates Akt and prevents serum starvation-induced cell death in neonatal rat cardiomyocytes. J Mol Cell Cardiol (2005) 39:841-4. doi:10.1016/j.yjmcc.2005. 07.019

41. Kenessey A, Ojamaa K. Thyroid hormone stimulates protein synthesis in the cardiomyocyte by activating the Akt-mTOR and p70S6K pathways. J Biol Chem (2006) 281:20666-72. doi:10.1074/jbc.M512671200

42. Belke DD, Gloss B, Swanson EA, Dillmann WH. Adeno-associated virusmediated expression of thyroid hormone receptor isoforms-alphal and -betal improves contractile function in pressure overload-induced cardiac hypertrophy. Endocrinology (2007) 148:2870-7. doi:10.1210/en.2007-0009

43. Klein I, Danzi S. Thyroid disease and the heart. Circulation (2007) 116:1725-35. doi:10.1161/CIRCULATIONAHA.106.678326

44. Forfar JC, Wathen CG, Todd WT, Bell GM, Hannan WJ, Muir AL, et al. Left ventricular performance in subclinical hypothyroidism. Q J Med (1985) 224:857-65.

45. Arem R, Rokey R, Kiefe C, Escalante DA, Rodriguez A. Cardiac systolic and diastolic function at rest and exercise in subclinical hypothyroidism: effect of thyroid hormone therapy. Thyroid (1996) 6:397-402. doi:10.1089/ thy.1996.6.397

46. Aghini-Lombardi F, Di Bello V, Talini E, Di Cori A, Monzani F, Antonangeli L, et al. Early textural and functional alterations of left ventricular myocardium in mild hypothyroidism. Eur J Endocrinol (2006) 155:3-9. doi:10.1530/eje.1.02174

47. Monzani F, Di Bello V, Caraccio N, Bertini A, Giorgi D, Giusti C, et al. Effect of levothyroxine on cardiac function and structure in subclinical hypothyroidism: a double blind; placebo-controlled study. J Clin Endocrinol Metab (2001) 86:1110-5. doi:10.1210/jcem.86.3.7291

48. Monzani F, Del Guerra P, Caraccio N, Pruneti CA, Pucci E, Luisi M, et al. Subclinical hypothyroidism: neurobehavioral features and beneficial effect of L-thyroxine treatment. Clin Investig (1993) 71:367-71.

49. Di Paola R, Alagona C, Pezzino V, Mangiameli S, Regalbuto C. Left ventricularfunction in acute hypothyroidism: a Doppler echocardiographystudy. Ital Heart J (2004) 5:857-63.

50. Ripoli A, Pingitore A, Favilli B, Bottoni A, Turchi S, Osman NF, et al. Does subclinical hypothyroidism affect cardiac pump performance? Evidence from a magnetic resonance imaging study. J Am Coll Cardiol (2005) 45:439-45. doi:10.1016/j.jacc.2004.10.044 
51. Nanchen D, Gussekloo J, Westendorp RG, Stott DJ, Jukema JW, Trompet S, et al. Subclinical thyroid dysfunction and the risk of heart failure in older persons at high cardiovascular risk. J Clin Endocrinol Metab (2012) 97:852-61. doi:10.1210/jc.2011-1978

52. Biondi B, Fazio S, Palmieri EA, Carella C, Panza N, Cittadini A, et al. Left ventricular diastolic dysfunction in patients with subclinical hypothyroidism. J Clin Endocrinol Metab (1999) 84:2064-7. doi:10.1210/jcem.84.6.5733

53. Büssemaker E, Popp R, Fisslthaler B, Larson CM, Fleming I, Busse R, et al. Hyperthyroidism enhances endothelium dependent relaxation in the rat renal artery. Cardiovasc Res (2003) 59:181-9. doi:10.1016/S0008-6363(03)00326-2

54. Carrillo-Sepúlveda MA, Ceravolo GS, Fortes ZB, Carvalho MH, Tostes RC, Laurindo FR, et al. Thyroid hormone stimulates NO production via activation of the PI3K/Akt pathway in vascular myocytes. Cardiovasc Res (2010) 85:560-70. doi:10.1093/cvr/cvp304

55. Dardano A, Ghiadoni L, Plantinga Y, Caraccio N, Bemi A, Duranti E, et al. Recombinant human thyrotropin reduces endothelium-dependent vasodilation in patients monitored for differentiated thyroid carcinoma. J Clin Endocrinol Metab (2006) 91:4175-8. doi:10.1210/jc.2006-0440

56. Fukuyama K, Ichiki T, Takeda K, Tokunou T, Iino N, Masuda S, et al. Down regulation of vascular angiotensin II type 1 receptor by thyroid hormone. Hypertension (2003) 41:598-603. doi:10.1161/01.HYP.0000056524.35294.80

57. Asvold BO, Bjøro T, Nilsen TI, Vatten LJ. Association between blood pressure and serum thyroid-stimulating hormone concentration within the reference range: a population-based study. J Clin Endocrinol Metab (2007) 92:841-5. doi:10.1210/jc.2006-2208

58. Fommei E, Iervasi G. The role of thyroid hormone in blood pressure homeostasis: evidence from short-term hypothyroidism in humans. JClin Endocrinol Metab (2002) 87:1996-2000. doi:10.1210/jcem.87.5.8464

59. Caraccio N, Natali A, Sironi A, Baldi S, Frascerra S, Dardano A, et al. Muscle metabolism and exercise tolerance in subclinical hypothyroidism: a controlled trial of levothyroxine. J Clin Endocrinol Metab (2005) 90:4057-62. doi:10.1210/jc.2004-2344

60. Monzani F, Caraccio N, Siciliano G, Manca L, Murri L, Ferrannini E. Clinical and biochemical features of muscle dysfunction in subclinical hypothyroidism. J Clin Endocrinol Metab (1997) 82:3315-8. doi:10.1210/jcem.82.10.4296

61. Jessup M, Abraham WT, Casey DE, Feldman AM, Francis GS, Ganiats TG, et al. Focused update: ACCF/AHA Guidelines for the Diagnosis and Management of Heart Failure in Adults: a report of the American College of Cardiology Foundation/American Heart Association Task Force on Practice Guidelines: developed in collaboration with the International Society for Heart and Lung Transplantation. Circulation (2009) 119:1977-2016. doi:10.1161/CIRCULATIONAHA.109.192064

62. Hunt SA, Abraham WT, Chin MH, Feldman AM, Francis GS, Ganiats TG, et al. Focused update incorporated into the ACC/AHA 2005 Guidelines for the Diagnosis and Management of Heart Failure in Adults A Report of the American College of Cardiology Foundation/American Heart Association Task Force on Practice Guidelines Developed in Collaboration With the International Society for Heart and Lung Transplantation. J Am Coll Cardiol (2009) 53:e1-90. doi:10.1016/j.jacc.2008.11.013

63. Bui AL, Horwich TB, Fonarow GC. Epidemiology and risk profile of heart failure. Nat Rev Cardiol (2011) 8:30-41. doi:10.1038/nrcardio.2010.165

64. Mann DL, Chakinala M. Heart failure and cor pulmonale. 18th ed. In: Longo DL, Fauci AS, Kasper DL, Hauser SL, Jameson JL, Loscalzo L, editors. Harrison's Principles of Internal Medicine. New York, NY: McGraw-Hill Companies (2011). p. 1901-15.

65. Pfuntner A, Wier LM, Stocks C. Most Frequent Conditions in U.S. Hospitals, 2011: HCUP Statistical Brief \#162. Rockville, MD: Agency for Healthcare Research and Quality (2013).

66. Ochs N, Auer R, Bauer DC, Nanchen D, Gussekloo J, Cornuz J, et al. Metaanalysis: subclinical thyroid dysfunction and the risk for coronary heart disease and mortality. Ann Intern Med (2008) 148:832-45. doi:10.7326/0003-4819148-11-200806030-00225

67. Rodondi N, Aujesky D, Vittinghoff E, Cornuz J, Bauer DC. Subclinical hypothyroidism and the risk of coronary heart disease: a meta-analysis. Am J Med (2006) 7:541-51. doi:10.1016/j.amjmed.2005.09.028

68. Monzani F, Dardano A, Caraccio N. Does treating subclinical hypothyroidism improve markers of cardiovascular risk? Treat Endocrinol (2006) 5:65-8. doi:10.2165/00024677-200605020-00001
69. Frey A, Kroiss M, Berliner D, Seifert M, Allolio B, Güder G, et al. Prognostic impact of subclinical thyroid dysfunction in heart failure. Int J Cardiol (2013) 168:300-5. doi:10.1016/j.ijcard.2012.09.064

70. Rodondi N, Bauer DC, Cappola AR, Cornuz J, Robbins J, Fried LP, et al. Subclinical thyroid dysfunction; cardiac function; and the risk of heart failure. The cardiovascular health study. J Am Coll Cardiol (2008) 52:1152-9. doi:10.1016/j.jacc.2008.07.009

71. Iacoviello M, Guida P, Guastamacchia E, Triggiani V, Forleo C, Catanzaro R, et al. Prognostic role of sub-clinical hypothyroidism in chronic heart failure outpatients. Curr Pharm Des (2008) 14:2686-92. doi:10.2174/ 138161208786264142

72. Rodondi N, Newman AB, Vittinghoff E, de Rekeneire N, Satterfield S, Harris $\mathrm{TB}$, et al. Subclinical hypothyroidism and the risk of heart failure, other cardiovascular events, and death. Arch Intern Med (2005) 165:2460-6. doi:10.1001/ archinte.165.21.2460

73. Iervasi G, Molinaro S, Landi P, Taddei MC, Galli E, Mariani F, et al. Association between increased mortality and mild thyroid dysfunction in cardiac patients. Arch Intern Med (2007) 167:1526-32. doi:10.1001/archinte.167.14.1526

74. Hyland KA, Arnold AM, Lee JS, Cappola AR. Persistent subclinical hypothyroidism and cardiovascular risk in the elderly: the cardiovascular health study. J Clin Endocrinol Metab (2013) 98:533-40. doi:10.1210/jc.2012-2180

75. Perez AC, Jhund PS, Stott DJ, Gullestad L, Cleland JG, van Veldhuisen DJ, et al. Thyroid-stimulating hormone and clinical outcomes: the CORONA trial (controlled rosuvastatin multinational study in heart failure). JACC Heart Fail (2014) 2:35-40. doi:10.1016/j.jchf.2013.07.008

76. Selmer C, Olesen JB, Hansen ML, von Kappelgaard LM, Madsen JC, Hansen $\mathrm{PR}$, et al. Subclinical and overt thyroid dysfunction and risk of all-cause mortality and cardiovascular events: a large population study. J Clin Endocrinol Metab (2014) 99:2372-82. doi:10.1210/jc.2013-4184

77. Gencer B, Collet TH, Virgini V, Bauer DC, Gussekloo J, Cappola AR, et al. Subclinical thyroid dysfunction and the risk of heart failure events: an individual participant data analysis from 6 prospective cohorts. Circulation (2012) 126:1040-9. doi:10.1161/CIRCULATIONAHA.112.096024

78. Imaizumi M, Akahoshi M, Ichimaru S, Nakashima E, Hida A, Soda M, et al. Risk for ischemic heart disease and all-cause mortality in subclinical hypothyroidism. J Clin Endocrinol Metab (2004) 89:3365-70. doi:10.1210/jc.2003031089

79. Boekholdt SM, Titan SM, Wiersinga WM, Chatterjee K, Basart DC, Luben $\mathrm{R}$, et al. Initial thyroid status and cardiovascular risk factors: the EPICNorfolk prospective population study. Clin Endocrinol (Oxf) (2010) 72:404-10. doi:10.1111/j.1365-2265.2009.03640.x

80. Cappola AR, Fried LP, Arnold AM, Danese MD, Kuller LH, Burke GL, et al. Thyroid status, cardiovascular risk, and mortality in older adults. JAMA (2006) 295:1033-41. doi:10.1001/jama.295.9.1033

81. Zhang Y, Chang Y, Ryu S, Cho J, Lee WY, Rhee EJ, et al. Thyroid hormones and mortality risk in euthyroid individuals: the Kangbuk samsung health study. J Clin Endocrinol Metab (2014) 34:2128-34. doi:10.1161/ATVBAHA. 114.303889

82. Yeap BB, Alfonso H, Hankey GJ, Flicker L, Golledge J, Norman PE, et al. Higher free thyroxine levels are associated with all-cause mortality in euthyroid older men: the health in men study. Eur J Endocrinol (2013) 12(169):401-8. doi:10.1530/EJE-13-0306

83. Parle JV, Maisonneuve P, Sheppard MC, Boyle P, Franklyn JA. Prediction of all-cause and cardiovascular mortality in elderly people from one low serum thyrotropin result: a 10-year cohort study. Lancet (2001) 358:861-5. doi:10.1016/S0140-6736(01)06067-6

84. Hak AE, Pols HA, Visser TJ, Drexhage HA, Hofman A, Witteman JC. Subclinical hypothyroidism is an independent risk factor for atherosclerosis and myocardial infarction in elderly women: the Rotterdam study. Ann Intern Med (2000) 132:270-8. doi:10.7326/0003-4819-132-4-200002150-00004

85. Lindeman RD, Romero LJ, Schade DS, Wayne S, Baumgartner RN, Garry PJ. Impact of subclinical hypothyroidism on serum total homocysteine concentrations, the prevalence of coronary heart disease (CHD), and CHD risk factors in the New Mexico Elder Health Survey. Thyroid (2003) 13:595-600. doi:10.1089/105072503322238863

86. Bauer DC, Rodondi N, Stone KL, Hillier TA; Study of Osteoporotic Fractures Research Group: Universities of California (San Francisco), Pittsburgh, Minnesota (Minneapolis); Kaiser Permanente Center for Health Research, 
Portland. Thyroid hormone use, hyperthyroidism and mortality in older women. Am J Med (2007) 120:343-9. doi:10.1016/j.amjmed.2006.04.034

87. McQuade C, Skugor M, Brennan DM, Hoar B, Stevenson C, Hoogwerf BJ. Hypothyroidism and moderate subclinical hypothyroidism are associated with increased all-cause mortality independent of coronary heart disease risk factors: aPreCIS database study. Thyroid (2011) 21:837-43. doi:10.1089/thy. 2010.0298

88. de Jongh RT, Lips P, van Schoor NM, Rijs KJ, Deeg DJ, Comijs HC, et al. Endogenous subclinical thyroid disorders, physical and cognitive function, depression, and mortality in older individuals. Eur J Endocrinol (2011) 165:545-54. doi:10.1530/EJE-11-0430

89. Waring AC, Harrison S, Samuels MH, Ensrud KE, LeBLanc ES, Hoffman AR, et al. Thyroid function and mortality in older men: a prospective study. J Clin Endocrinol Metab (2012) 97:862-70. doi:10.1210/jc.2011-2684

90. LeGrys VA, Funk MJ, Lorenz CE, Giri A, Jackson RD, Manson JE, et al. Subclinical hypothyroidism and risk for incident myocardial infarction among postmenopausal women. J Clin Endocrinol Metab (2013) 98:2308-17. doi:10. 1210/jc.2012-4065

91. Rhee CM, Curhan GC, Alexander EK, Bhan I, Brunelli SM. Subclinical hypothyroidism and survival: the effects of heart failure and race. J Clin Endocrinol Metab (2013) 98:2326-36. doi:10.1210/jc.2013-1039

92. Ceresini G, Ceda GP, Lauretani F, Maggio M, Usberti E, Marina M, et al. Thyroid status and 6-year mortality in elderly people living in a mildly iodine-deficient area: the aging in the Chianti Area Study. J Am Geriatr Soc (2013) 61:868-74. doi:10.1111/jgs. 12267

93. Rodondi N, den Elzen WP, Bauer DC, Cappola AR, Razvi S, Walsh JP, et al. Subclinical hypothyroidism and the risk of coronary heart disease and mortality. JAMA (2010) 304:1365-74. doi:10.1001/jama.2010.1361

94. Kvetny J, Heldgaard PE, Bladbjerg EM, Gram J. Subclinical hypothyroidism is associated with a low-grade inflammation, increased triglyceride levels and predicts cardiovascular disease in males below 50 years. Clin Endocrinol (Oxf) (2004) 61:232-8. doi:10.1111/j.1365-2265.2004.02088.x

95. Razvi S, Shakoor A, Vanderpump M, Weaver JU, Pearce SH. The influence of age on the relationship between subclinical hypothyroidism and ischemic heart disease: a metaanalysis. J Clin Endocrinol Metab (2008) 93:2998-3007. doi:10.1210/jc.2008-0167

96. Simonsick EM, Newman AB, Ferrucci L, Satterfield S, Harris TB, Rodondi N, et al. Subclinical hypothyroidism and functional mobility in older adults. Arch Intern Med (2009) 169:2011-7. doi:10.1001/archinternmed.2009.392

97. Singh S, Duggal J, Molnar J, Maldonado F, Barsano CP, Arora R. Impact of subclinical thyroid disorders on coronary heart disease, cardiovascular and all-cause mortality: a meta-analysis. Int J Cardiol (2008) 125:41-8. doi:10.1016/j.ijcard.2007.02.027

98. Giri A, Edwards TL, LeGrys VA, Lorenz CE, Funk MJ, Schectman R, et al. Subclinical hypothyroidism and risk for incident ischemic stroke among postmenopausal women. Thyroid (2014) 24:1210-7. doi:10.1089/thy.2014. 0106

99. Schultz M, Kistorp C, Raymond I, Dimsits J, Tuxen C, Hildebrandt P, et al. Cardiovascular events in thyroid disease: a population based, prospective study. Horm Metab Res (2011) 43:653-9. doi:10.1055/s-0031-1283162

100. Baek JH, Chung PW, Kim YB, Moon HS, Suh BC, Jin DK, et al. Favorable influence of subclinical hypothyroidism on the functional outcomes in stroke patients. Endocr J (2010) 57:23-9. doi:10.1507/endocri.K09E-206

101. Molinaro S, Iervasi G, Lorenzoni V, Coceani M, Landi P, Srebot V, et al. Persistence of mortality risk in patients with acute cardiac diseases and mild thyroid dysfunction. Am J Med Sci (2012) 343:65-70. doi:10.1097/MAJ. 0b013e31822846bd

102. Haentjens P, Van Meerhaeghe A, Poppe K, Velkeniers B. Subclinical thyroid dysfunction and mortality: an estimate of relative and absolute excess all-cause mortality based on time-to-event data from cohort studies. Eur J Endocrinol (2008) 159:329-41. doi:10.1530/EJE-08-0110

103. Meier C, Staub JJ, Roth CB, Guglielmetti M, Kunz M, Miserez AR, et al. TSH-controlled L-thyroxine therapy reduces cholesterol levels and clinical symptoms in subclinical hypothyroidism: a double blind, placebo-controlled trial (Basel Thyroid Study). J Clin Endocrinol Metab (2001) 86:4860-6. doi:10.1210/jcem.86.10.7973

104. Caraccio N, Ferrannini E, Monzani F. Lipoprotein profile in subclinical hypothyroidism: response to levothyroxine replacement, a randomized placebo-controlled study. J Clin Endocrinol Metab (2002) 87:1533-8. doi:10. 1210/jcem.87.4.8378

105. Cooper DS, Halpern R, Wood LC, Levin AA, Ridgway ECL. Thyroxine therapy in subclinical hypothyroidism. A double-blind, placebo-controlled trial. Ann Intern Med (1984) 101:18-24. doi:10.7326/0003-4819-101-1-18

106. Jaeschke R, Guyatt G, Gerstein H, Patterson C, Molloy W, Cook D, et al. Does treatment with $\mathrm{L}$-thyroxine influence health status in middle-aged and older adults with subclinical hypothyroidism? J Gen Intern Med (1996) 11:744-9. doi:10.1007/BF02598988

107. Kong WM, Sheikh MH, Lumb PJ, Naoumova RP, Freedman DB, Crook M, et al. A 6-month randomized trial of thyroxine treatment in women with mild subclinical hypothyroidism. Am J Med (2002) 112:348-54. doi:10.1016/S00029343(02)01022-7

108. Nyström E, Caidahl K, Fager G, Wikkelsö C, Lundberg PA, Lindstedt G. A double-blind cross-over 12-month study of L-thyroxine treatment of women with "subclinical" hypothyroidism. Clin Endocrinol (Oxf) (1988) 29:63-75. doi:10.1111/j.1365-2265.1988.tb00250.x

109. Wilkes S, Pearce S, Ryan V, Rapley T, Ingoe L, Razvi S. Study of optimal replacement of thyroxine in the ElDerly (SORTED): protocol for a mixed methods feasibility study to assess the clinical utility of lower dose thyroxine in elderly hypothyroid patients: study protocol for a randomized controlled trial. Trials (2013) 14:83. doi:10.1186/1745-6215-14-83

110. The WHOQOL Group. The World Health Organization Quality Of Life Assessment (WHOQOL): position paper from the World Health Organization. Soc Sci Med (1995) 41:1403-9. doi:10.1016/0277-9536(95)00112-K

111. Razvi S, Ingoe LE, McMillan CV, Weaver JU. Health status in patients with sub-clinical hypothyroidism. Eur J Endocrinol (2005) 152:713-7. doi:10.1530/ eje.1.01907

112. Bianchi GP, Zaccheroni V, Solaroli E, Vescini F, Cerutti R, Zoli M, et al. Healthrelated quality of life in patients with thyroid disorders. Qual Life Res (2004) 13:45-54. doi:10.1023/B:QURE.0000015315.35184.66

113. Walsh JP, Shiels L, Lim EM, Bhagat CI, Ward LC, Stuckey BG, et al. Combined thyroxine/liothyronine treatment does not improve wellbeing, quality of life, or cognitive function compared to thyroxine alone: a randomized controlled trial in patients with primary hypothyroidism. J Clin Endocrinol Metab (2003) 88:4543-50. doi:10.1210/jc.2003-030249

114. Klaver EI, van Loon HC, Stienstra R, Links TP, Keers JC, Kema IP, et al. Thyroid hormone status and health-related quality of life in the LifeLines Cohort Study. Thyroid (2013) 23:1066-73. doi:10.1089/thy.2013.0017

115. Bell RJ, Rivera-Woll L, Davison SL, Topliss DJ, Donath S, Davis SR. Well-being, health-related quality of life and cardiovascular disease risk profile in women with subclinical thyroid disease - a community-based study. Clin Endocrinol (Oxf) (2007) 66:548-56.

116. McMillan CV, Bradley C, Woodcock A, Razvi S, Weaver JU. Design of new questionnaires to measure quality of life and treatment satisfaction in hypothyroidism. Thyroid (2004) 14:916-25. doi:10.1089/thy.2004.14.916

117. McMillan C, Bradley C, Razvi S, Weaver J. Evaluation of new measures of the impact of hypothyroidism on quality of life and symptoms: the ThyDQoL and ThySRQ. Value Health (2008) 11:285-94. doi:10.1111/j.1524-4733.2007. 00232.x

118. Razvi S, McMillan CV, Weaver JU. Instruments used in measuring symptoms, health status and quality of life in hypothyroidism: a systematic qualitative review. Clin Endocrinol (Oxf) (2005) 63:617-24. doi:10.1111/j.1365-2265.2005. 02381.x

119. Quinque EM, Villringer A, Kratzsch J, Karger S. Patient-reported outcomes in adequately treated hypothyroidism - insights from the German versions of ThyDQoL, ThySRQ and ThyTSQ. Health Qual Life Outcomes (2013) 11:68. doi:10.1186/1477-7525-11-68

120. Chueire VB, Romaldini JH, Ward LS. Subclinical hypothyroidism increases the risk for depression in the elderly. Arch Gerontol Geriatr (2007) 44:21-8. doi:10.1016/j.archger.2006.02.001

121. Wu EL, Chien IC, Lin CH, Chou YJ, Chou P. Increased risk of hypothyroidism and hyperthyroidism in patients with major depressive disorder: a populationbased study. J Psychosom Res (2013) 74:233-7. doi:10.1016/j.jpsychores.2012. 12.016

122. Jaeschke R, Guyatt G, Cook D, Harper S, Gerstein HC. Spectrum of quality of life impairment in hypothyroidism. Qual Life Res (1994) 3:323-7. doi:10.1007/BF00451724 
123. Mainenti MR, Vigário PS, Teixeira PF, Maia MD, Oliveira FP, Vaisman M. Effect of levothyroxine replacement on exercise performance in subclinical hypothyroidism. J Endocrinol Invest (2009) 32:470-3. doi:10.3275/6106

124. Reuters VS, Teixeira Pde F, Vigário PS, Almeida CP, Buescu A, Ferreira $\mathrm{MM}$, et al. Functional capacity and muscular abnormalities in subclinical hypothyroidism. Am J Med Sci (2009) 338:259-63. doi:10.1097/MAJ. 0b013e3181af7c7c

125. Gulseren S, Gulseren L, Hekimsoy Z, Cetinay P, Ozen C, Tokatlioglu B. Depression, anxiety, health-related quality of life, and disability in patients with overt and subclinical thyroid dysfunction. Arch Med Res (2006) 37:133-9. doi:10.1016/j.arcmed.2005.05.008

126. Park YJ, Lee EJ, Lee YJ, Choi SH, Park JH, Lee SB, et al. Subclinical hypothyroidism $(\mathrm{SCH})$ is not associated with metabolic derangement, cognitive impairment, depression or poor quality of life (QoL) in elderly subjects. Arch Gerontol Geriatr (2010) 50:e68-73. doi:10.1016/j.archger.2009. 05.015

127. Vigário P, Teixeira P, Reuters V, Almeida C, Maia M, Silva M, et al. Perceived health status of women with overt and subclinical hypothyroidism. Med Princ Pract (2009) 18:317-22. doi:10.1159/000215731

128. Jorde R, Waterloo K, Storhaug H, Nyrnes A, Sundsfjord J, Jenssen TG. Neuropsychological function and symptoms in subjects with subclinical hypothyroidism and the effect of thyroxine treatment. J Clin Endocrinol Metab (2006) 91:145-53. doi:10.1210/jc.2005-1775

129. Razvi S, Ingoe L, Keeka G, Oates C, McMillan C, Weaver JU. The beneficial effect of L-thyroxine on cardiovascular risk factors, endothelial function, and quality of life in subclinical hypothyroidism: randomized, crossover trial. J Clin Endocrinol Metab (2007) 92:1715-23. doi:10.1210/jc. 2006-1869

130. Reuters VS, Almeida Cde P, TeixeiraPde F, VigárioPdos S, Ferreira MM, Castro $\mathrm{CL}$, et al. Effects of subclinical hypothyroidism treatment on psychiatric symptoms, muscular complaints, and quality of life. Arq Bras Endocrinol Metabol (2012) 56:128-36.

131. Baldini M, Colasanti A, Orsatti A, Airaghi L, Mauri MC, Cappellini MD. Neuropsychological functions and metabolic aspects in subclinical hypothyroidism: the effects of L-thyroxine. Prog Neuropsychopharmacol Biol Psychiatry (2009) 33:854-9. doi:10.1016/j.pnpbp.2009.04.009

132. Esposito SM, Haggerty JJ, Stern RA. Geropsychiatric effects of subclinicl hypothyroidism. Paper presented at the 147th Annual Meeting of the American Psychiatric Association. Philadelphia, PA (1994).

133. Formiga F, Ferrer A, Padros G, Contra A, Corbella X, Pujol R, et al. Thyroid status and functional and cognitive status at baseline and survival after 3 years of follow-up: the OCTABAIX study. Eur J Endocrinol (2013) 170:69-75. doi:10.1530/EJE-13-0722

134. Virgini VS, Wijsman LW, Rodondi N, Bauer DC, Kearney PM, Gussekloo J, et al. Subclinical thyroid dysfunction and functional capacity among elderly. Thyroid (2014) 24:208-14. doi:10.1089/thy.2013.0071

135. Kahapola-Arachchige KM, Hadlow N, Wardrop R, Lim EM, Walsh JP. Agespecific TSH reference ranges have minimal impact on the diagnosis of thyroid dysfunction. Clin Endocrinol (Oxf) (2012) 77:773-9. doi:10.1111/j.1365-2265. 2012.04463.x

Conflict of Interest Statement: The authors declare that the research was conducted in the absence of any commercial or financial relationships that could be construed as a potential conflict of interest.

Received: 18 June 2014; accepted: 12 September 2014; published online: 07 October 2014

Citation: Tognini S, Pasqualetti G, Calsolaro V, Polini A, Caraccio N and Monzani F (2014) Cardiovascular risk and quality of life in elderly people with mild thyroid hormone deficiency. Front. Endocrinol. 5:153. doi: 10.3389/fendo.2014.00153

This article was submitted to Endocrinology of Aging, a section of the journal Frontiers in Endocrinology.

Copyright (c) 2014 Tognini, Pasqualetti, Calsolaro, Polini, Caraccio and Monzani. This is an open-access article distributed under the terms of the Creative Commons Attribution License (CC BY). The use, distribution or reproduction in other forums is permitted, provided the original author(s) or licensor are credited and that the original publication in this journal is cited, in accordance with accepted academic practice. No use, distribution or reproduction is permitted which does not comply with these terms. 